\title{
Utilization of Produced Heat in Motorcycle Exhaust as a Mobile Battery Charger Using Thermoelectric Seebeck Generator
}

\author{
Eko Naibaho ${ }^{1^{*}}$ and Takdir Tamba ${ }^{2}$ \\ ${ }^{1,2}$ Department of Physics, Faculty of Mathematics and Natural Science, Universitas Sumatera Utara, \\ Medan 20155, Indonesia
}

\begin{abstract}
Produced heat from motorcycle exhaust has been used to recharge cellphone batteries using a thermoelectric seebeck generator and program settings from the Arduino microcontroller. This tool consists of an LM 35 sensor that functions as a temperature reader, TEG as a heat converter to voltage, DC to DC Booster as a voltage controller, Arduino Uno as a data processor, LCD as a display. The software in this tool uses the Arduino IDE program. This tool is used to convert heat into voltage. The working principle of this system in general is that when the exhaust heat is removed, the controller will read the data from the LM 35 temperature sensor. After that the data will be processed by the microcontroller. After obtaining the processed data, the result data is then displayed on the LCD and the relay circuit will activate the system when the required voltage is appropriate.
\end{abstract}

Keyword: Arduino Uno, TEG, Temperature Censor LM 35, Cell Phone.

Received 19 August 2021 | Revised [23 August 2021] | Accepted [27 August 2021]

\section{Introduction}

The law of conservation of energy states that energy cannot be created or destroyed but can be transformed from one form to another. One example of energy used in everyday life is electrical energy. Electrical energy is generated from kinetic energy in dynamos resulting in heat energy. Heat energy generated from burning coal and geothermal [1].

The world's energy use is increasing, but energy-producing fuel sources are not growing rapidly against the pace of energy consumption. Especially in Indonesia where the use of fuel in motor vehicles is quite high. According to data published by the Central Statistics Agency, the number of motorcycle population in Indonesia until 2013 amounted to 84 million units. Each combustion engine produces a percentage of the energy stored in the fuel converted into heat energy generated from the combustion process. The heat energy produced by the machine is energy wasted into the environment. Therefore, the heat energy generated from combustion

\footnotetext{
*Corresponding author at: Jalan Bioteknologi no.1 Medan, 20155, Indonesia

E-mail address: komarho77@gmail.com
} 
should be reused into energy that is beneficial for the environment. One technology that can utilize waste heat energy is thermoelectric generator (TEG) [2]. TEG technology utilizes the temperature difference that occurs between high and low temperatures so that it can produce an electric current. If the result of the temperature difference of this TEG technology is getting bigger then this condition will make the electric current produced even greater. By utilizing the exhaust gas heat generated from combustion through the exhaust, this condition can be made into electrical energy. The electrical energy generated by TEG can be used to charge mobile phone batteries. By using one or more TEGs arranged and combined with voltage and current regulators, the electricity can be used to charge mobile phone batteries [3].

Thermoelectric generators were invented from the theory of German physicist Thomas Johann Seebeck in 1826. This theory states that two semiconductor materials of different types if each surface has a different (gradient) temperature will produce an electrical voltage. Thermoelecttric generators are derived from the seebeck effect. If heat is applied to the circuit in the connection of two different conductors, an electric current will be generated. The device is solid state and unlike this dynamo that has moving parts so that it does not cause sound when performing the operation work of the device.

Thomas Johan Seebeck observed that the voltage produced is proportional to the difference in temperature and depends on the type of conductor material, but is not affected by the spread of temperature throughout the conductor. Seebeck tested a variety of materials, including naturally found semiconductors $\mathrm{ZnSb}$ and $\mathrm{PbS}$. The seebeck coefficient is the circuit open voltage generated between two points on the conductor, when a uniform temperature difference of $1 \mathrm{~K}$ is applied between the two points. The simplest thermoelectric generator consists of a thermocouple consisting of type $\mathrm{n}$ (material with excess electrons) and type $\mathrm{p}$ (material with electron deficiency) elements connected in series and heat [4].

In parallel, heat is input from one side and is rejected from the other, producing voltage across thermoelectric pairs. The amount of voltage generated is proportional to the temperature gradient of the peltier element. Thermoelectric is a device that uses the peltier principle application, where when an electric current is flowed on the connection of two types of metals it will produce heat transfer [5].

Two semiconductor materials of different types if each surface has a different (gradient) of the texture will produce an electrical voltage. This condition is further known as the seebeck effect. This equation is given with the formula (1)

$$
S=\mathrm{V} / \Delta \mathrm{T}
$$


$\mathrm{S}$ is the seebeck coefficient $(\mathrm{V} / \mathrm{K}), \mathrm{V}$ is voltage generated (volt) and $\Delta \mathrm{T}$ is different side temperature heat sink heat and cold heat sink (kelvin).

Thermoelectric generators use thermoelectric effects. Thermoelectric effect can convert the difference in temperature becomes the electrical voltage directly. This thermoelectric effect includes three separate effects: seebeck effect, peltier effect, and thomson effect. According to Seebeck, a voltage will arise in a series of two different materials if the two deviations are maintained at different temperatures [6]-[10]. Thermoelectric power flow is a closed heat flow that works like a fluid flow, so the thermal efficiency of thermoelectrics depends between high temperature or hot temperature (TH) and low temperature or cold temperature (TL). Equation (1) is a voltage equation produced by a thermoelectric circuit. The seebeck coefficient for metals is relatively small, so for manufacturing developments, metal materials are replaced with semiconductor materials. An example of a semiconductor material is germanium-silicon. It has a coefficient of $830 \mu \mathrm{V} / \mathrm{K}$, greater than an iron metal that has only a coefficient of $60.6 \mu \mathrm{V} / \mathrm{K}$.

$$
V=\int_{T 1}^{T 2}[\alpha B(T)-\alpha A(T)] d T
$$

The peltier effect explains the difference in temperature produced by voltage and is the opposite of the seebeck effect. Based on the Thomson effect, the resulting seebeck coefficient is not constant to temperature [11]-[15].

We can accept that the gradient of the temperature as the gradient of the seebeck coefficient. Power generation by utilizing thermoelectric effects is known as Thermoelectric Generator. Thermoelecttric Generators use the basic principle of the seebeck effect. By utilizing the seedbeck effect, the potential heat wasted on this earth can be utilized more optimally [16]-[19].

Battery charger is a tool that serves to charge the battery with a constant voltage until it reaches the voltage formed. When the voltage formed has been reached, then the charging current will drop automatically after setting and holding the charging current so that it becomes slower so that the indicator is on indicating the battery has been fully charged. The scattering process is done by striking the charger connector on mobile devices [20]. In this study will be refilled mobile phone batteries using the heat exhaust of the motorcycle. Utilization of this heat uses a thermoelectric seedbeck generator.

\section{Methods}

This research was conducted in the Physics Laboratory, Digital Systems Laboratory, and Basic Electronics Laboratory of the University of North Sumatra which includes tool design, tool testing, sample testing and data analysis. 


\subsection{Functional Design}

Exhaust heat utilization tool as a mobile phone battery charger designed with several components, namely: Load as voltage output, TEG as heat converter into electricity, LCD as temperature viewer, DC to DC Booster as voltage controller, Voltage Sensor to measure voltage, Microcontroller to execute commands, and SD Card to store results data.

\subsection{Structural Design}

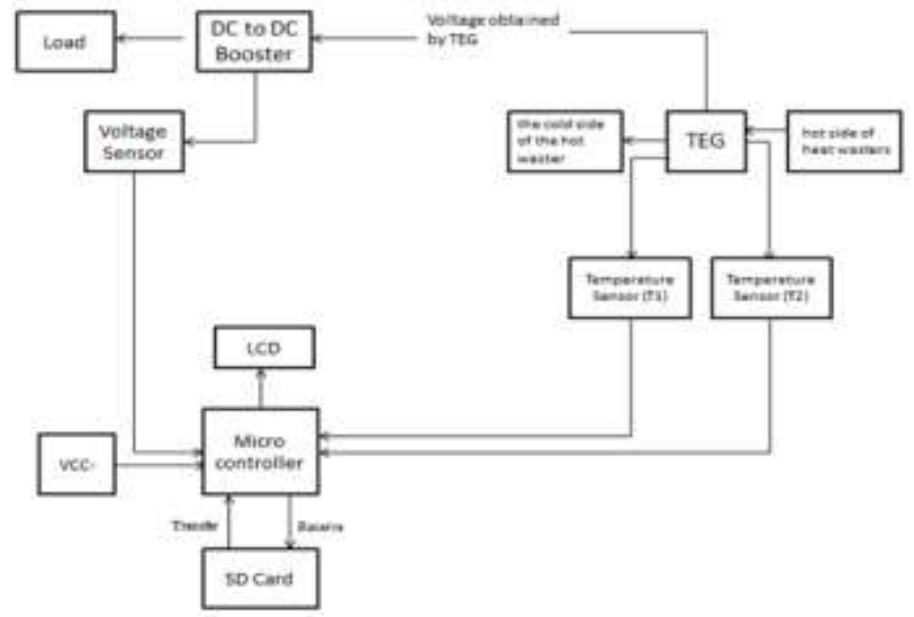

Figure 1. TEG Charger Working Principles

Structural design of TEG charger consisting of Load, TEG, LCD, DC to DC Booster, Voltage Sensor, Microcontroller, Keypad, and SD Card.

\subsection{Flowchart}

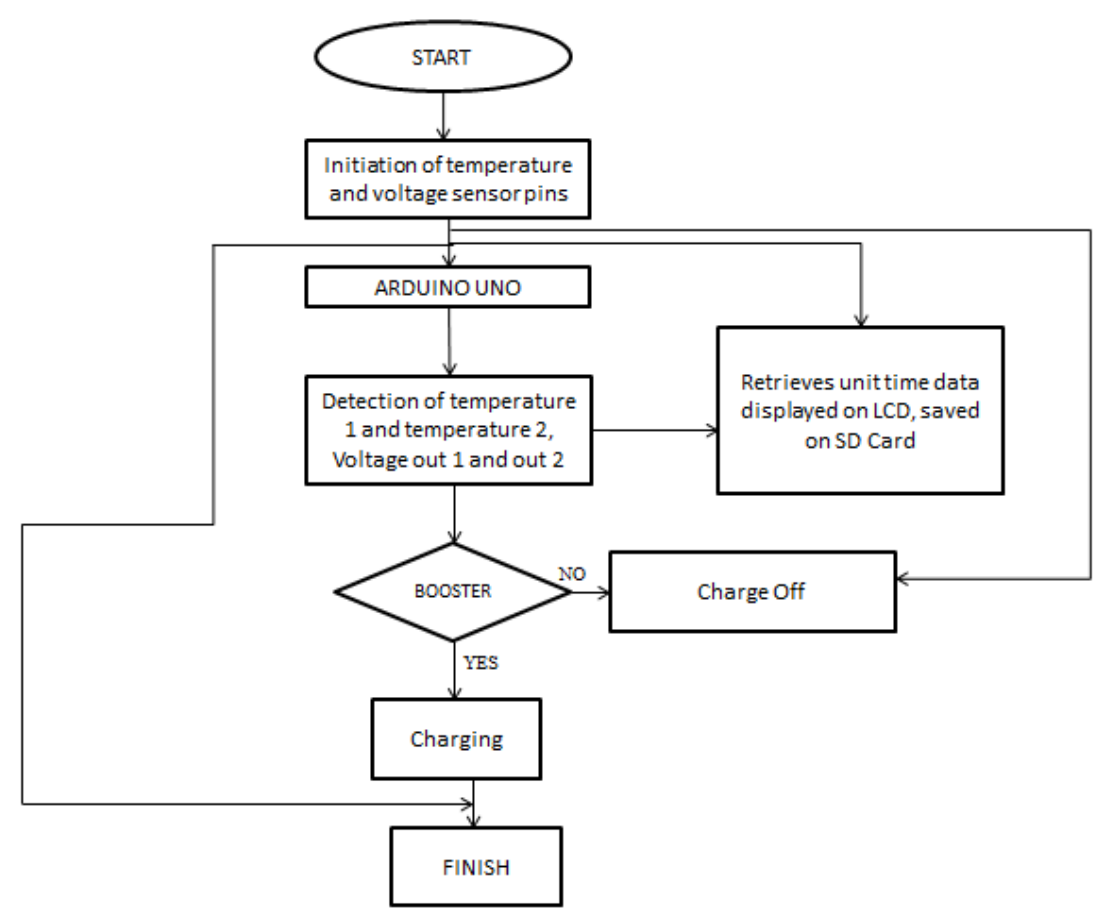

Figure 2. Flowchart of the system 


\section{Result and Discussion}

\subsection{LM 35 Sensor Testing}

LM 35 sensor testing is performed using an analog thermometer calibration tool. This test aims to determine the accuracy of the LM 35 sensor in reading the temperature with the pin configuration displayed in Table 1.

Table 1. Sensor Testing Data

\begin{tabular}{cc}
\hline Pin Arduini uno & LM 35 \\
\hline VCC & VCC \\
GND & Gnd \\
A1 & Out Data \\
LM 35 & Calibration \\
30.02 & 30 \\
44,09 & 45 \\
50,05 & 50 \\
67,04 & 67 \\
\hline
\end{tabular}

\subsection{Voltage Sensor Testing}

Voltage sensor testing is done to find out the value of the sensor output voltage that has been converted in the form of a 10 bit binary number. Voltage sensor testing uses a series of voltage dividers. The reading of this voltage sensor is an analog signal on the Arduino analog pin that contains an ADC (analog to digital converter) with a resolution of 10 bits. The results of this test are displayed in the range of values $0-1023$ from 0 to 5 Volts. The voltage divider serves to expand the voltage reading range so as not to damage the microcontroller. In this study, the voltage sensor used resistors of $670 \mathrm{k}$ and $10 \mathrm{k}$, so that the maximum voltage that can be read is 5 Volts. Voltage sensor testing is done to test the voltage sensor reading compared to the voltage reading done using a multimeter. This test was conducted as many as 15 times using input voltage from the variable power supply.

Table 2. Voltage sensor data

\begin{tabular}{cccccc}
\hline Testing for $\begin{array}{c}\text { Multimeter } \\
\text { (Volt) }\end{array}$ & $\begin{array}{c}\text { Value } \\
\text { ADC }\end{array}$ & $\begin{array}{c}\text { Sensor Reading } \\
\text { after calibration (V) }\end{array}$ & Error (V) & $\begin{array}{c}\text { Persentase } \\
(\%)\end{array}$ \\
\hline 1 & 40 & 121 & 41,24 & 1,24 & 3,1 \\
2 & 60 & 179 & 61,96 & 1,96 & 3,26 \\
3 & 80 & 237 & 83,34 & 3,34 & 4,17 \\
4 & 100 & 302 & 104,19 & 4,19 & 4,19 \\
5 & 120 & 360 & 124,94 & 4, & 4,11 \\
6 & 140 & 424 & 144,76 & 4,76 & 3,4 \\
7 & 160 & 483 & 164,93 & 4,93 & 3,08 \\
8 & 180 & 539 & 184,19 & 4,19 & 2,32 \\
9 & 200 & 604 & 204,26 & 4,26 & 2,13 \\
10 & 220 & 665 & 224,34 & 4,34 & 1,97 \\
11 & 240 & 728 & 245,59 & 5,59 & 2,32 \\
12 & 260 & 788 & 264,84 & 4,84 & 1,86
\end{tabular}




\begin{tabular}{cccccc}
\hline Testing for $\begin{array}{c}\text { Multimeter } \\
\text { (Volt) }\end{array}$ & $\begin{array}{c}\text { Value } \\
\text { ADC }\end{array}$ & $\begin{array}{c}\text { Sensor Reading } \\
\text { after calibration (V) }\end{array}$ & Error (V) & $\begin{array}{c}\text { Persentase } \\
(\%)\end{array}$ \\
\hline 13 & 280 & 851 & 286,19 & 6,19 & 2,21 \\
14 & 300 & 911 & 305,19 & 5,19 & 1,73 \\
15 & 320 & 976 & 327,98 & 7,98 & 2,49 \\
Average & & & & 4,52 & 2,82 \\
\hline
\end{tabular}

\subsection{Overall Cooler Testing in Heat Disposing}

In this section the temperature will be steamed i.e. the temperature of the hot and cold peltier part shown in Table 3.

Table 3. Temperature and Voltage Testing

\begin{tabular}{|c|c|c|c|c|c|}
\hline $\begin{array}{c}\text { Compute } \\
\text { Time }\end{array}$ & $\begin{array}{c}\text { Time } \\
\text { (mili sec.) }\end{array}$ & $\begin{array}{c}\text { T1 } \\
\text { (Heat) }\end{array}$ & $\begin{array}{c}\text { T2 } \\
\text { (Cool) }\end{array}$ & $\mathbf{V}_{\text {in }}$ & $\mathbf{V}_{\text {Out }}$ \\
\hline $23: 13: 11$ & $\overline{0}$ & 38,8 & 27,02 & 0,44 & 3,58 \\
\hline $23: 13: 12$ & 0 & 38,31 & 27,51 & 0,44 & 3,58 \\
\hline $23: 20: 28$ & 0 & 72,21 & 25,54 & 2,22 & 4,7 \\
\hline $23: 20: 29$ & 0 & 70,24 & 25,05 & 2,18 & 4,7 \\
\hline $23: 21: 08$ & 0 & 71,22 & 24,56 & 2,3 & 4,75 \\
\hline $23: 21: 09$ & 0 & 70,24 & 26,03 & 2,3 & 4,65 \\
\hline $23: 22: 04$ & 0 & 74,17 & 24,56 & 2,44 & 4,75 \\
\hline $23: 22: 05$ & 0 & 74,17 & 24,56 & 2,35 & 4,75 \\
\hline $23: 23: 05$ & 0 & 76,14 & 24,07 & 2,45 & 4,75 \\
\hline $23: 23: 06$ & 0 & 77,12 & 25,05 & 2,49 & 4,75 \\
\hline $23: 24: 06$ & 0 & 75,64 & 24,07 & 2,47 & 4,7 \\
\hline $23: 24: 07$ & 0 & 75,15 & 24,56 & 2,49 & 4,75 \\
\hline $23: 25: 06$ & 0 & 75,64 & 24,56 & 2,52 & 4,75 \\
\hline $23: 25: 07$ & 0 & 77,12 & 24,56 & 2,53 & 4,7 \\
\hline $23: 26: 02$ & 0 & 77,61 & 24,07 & 2,54 & 4,7 \\
\hline \multirow[t]{2}{*}{$23: 26: 03$} & 0 & 77,12 & 24,07 & 2,54 & 4,7 \\
\hline & & 70,0562 & 24,99 & 2,1687 & 4,5787 \\
\hline
\end{tabular}

After taking data for 13 minutes, the exhaust heat measured by the temperature sensor (T1) has an average value of $70.05625{ }^{\circ} \mathrm{C}$, the temperature (T2) has an average value of $24.99{ }^{\circ} \mathrm{C}$ and produces a voltage measured by the voltage sensor $\mathrm{V}_{\text {in }}$ with an average of $2.16875 \mathrm{~V}$. Then the test results using a boost converter produce an average $\mathrm{V}_{\text {out }}$ of $4.57875 \mathrm{~V}$. The temperature test curve is shown in Figure 3. 


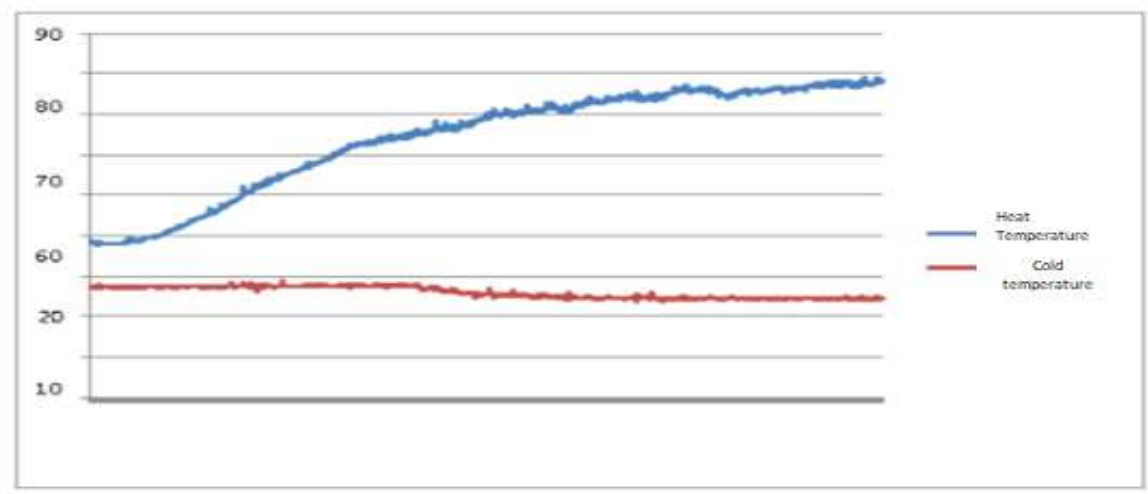

Figure 3. Temperature Testing Graph (C) and Time (Sec)

In this case it is also measured how much V in peltier and V Out of the dc to dc frame in battery charging:

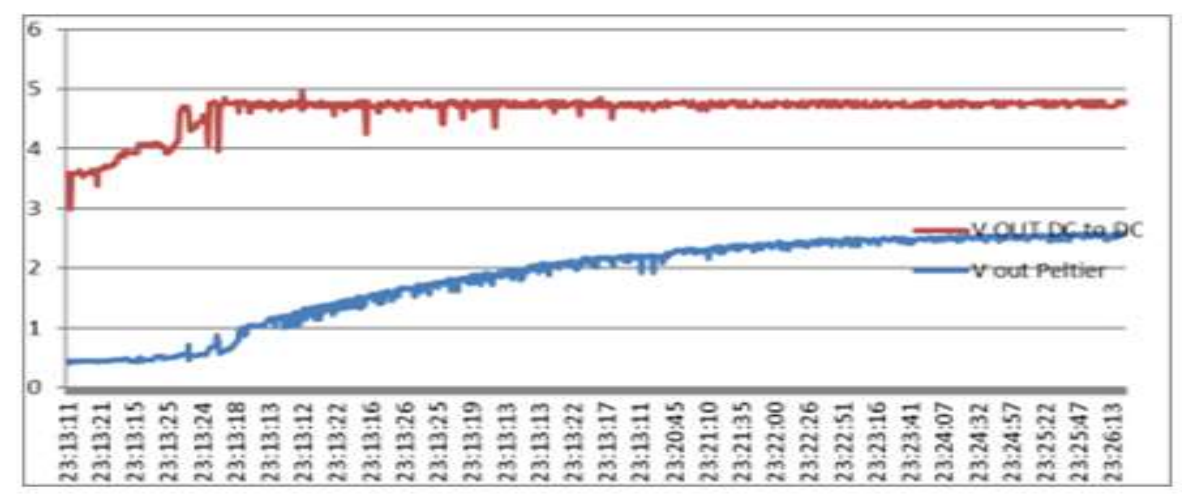

Figure 4. Voltage (V) and Time Testing Graph (Sec)

Figure 4 shows that the red line is the result of the output voltage of the DC to DC converter and the blue line is the result of the output voltage of the main component in this study, namely TEG.

\section{Conclusion}

The heat generated by knlapot can be converted into electrical energy using TEG as an eketronic component of $\mathrm{p}$ and type $\mathrm{n}$ semiconductors. The temperature difference between heat and cold throughout the converter produces a direct current to the load in the form of a voltage value of volt $(\mathrm{V})$. Data collection for 13 minutes obtained exhaust heat results measured by temperature sensor (T1) has an average value of $70.05625^{\circ} \mathrm{C}$, temperature (T2) has an average value of $24.99{ }^{\circ} \mathrm{C}$ and voltage measured by $\mathrm{V}_{\text {in }}$ voltage sensor with an average of $2.16875 \mathrm{~V}$. Then boosted by boost converter with an average $\mathrm{V}_{\text {out }}$ of $4.57875 \mathrm{~V}$. From the calculation is known the measurement accuracy value of $2.82 \%$ for voltage measurement. This is because the quality of the components used is not pure value. 


\section{REFERENCES}

[1] S. Moestikahadi, Pencemaran Udara, Bandung: Penerbit IT, 2000.

[2] Arie Wibawa, Bayu, Tata Guna Lahan dan Transportasi dalam Pembangunan Berkelanjutan di Jakata, Jakarta: Program Pasca Sarjana Magister Teknik Arsiterktur Universitas Diponegoro, 1996.

[3] A. Sjafruddin, Tantangan Menuju Sistem Transportasi Berkelanjutan, Medan: Seminar Nasional Tantangan Transportasi Perkotaan Menghadapi Millenium III, 2000.

[4] G.T. Miller, Living in The Environment: An Introduction to Environmental Science, California: Wadsworth Publishing Company Inc., 1985.

[5] K. Sembiring, Pemanfaatan Sumber Daya Lokal Mendukung Pembangunan Daerah dibutuhkan Sistem Transportasi Berkelanjutan, Medan: Seminar Nasional FMIPA/UNIMED, 2002.

[6] B. Jang, S. Han, and J. Y. Kim. "Optimal design for micro-thermoelectric generators using finite element analysis." Microelectronic Engineering, vol. 88, no. 5, pp. 775-778, 2011.

[7] Koestoer, R. Artono, Potensi Pembangkit Daya Termoelektrik untuk Kendaraan Hibrid, Depok: Fakultas Teknik Universitas Indonesia, 2009.

[8] Setyawan and S. B. Eko, Buku Pintar Sepeda Motor Panduan Praktis Pengguna Sepeda Motor, Yogyakarta: Media Pressindo, 2010.

[9] N. Putra, R. A. Koestoer, M. Adhitya, A. Roekettino, and B. Trianto, Potensi Pembangkit Daya Termoelektrik untuk Kendaraan Hibrid, Laboratorium Perpindahan Kalor, Depok: Fakultas Teknik Universitas Indonesia, 2009.

[10] A. R. Budi, Optimasi Pemanfaatan Panas Buang Pada Tungku Gasifikasi Biomassa Sebagai Penhasil Listrik, Riau: FT-Universitas Muhammadiyah Riau, 2014.

[11] Rowe, David Michael, ed. CRC handbook of thermoelectrics. CRC press, 2018.

[12] R.K. Rajput, Thermal Engineering, New Delhi: Print Man, 2010.

[13] O. Richard, Buckius, and J. Howell, Fundamentals of Engineering Thermodynamics, New York: McGraw-Hill, 1987.

[14] D. M. Roe and G. Min., Handbook of thermoelectrics, Peltier devices as generator", Florida: CRC Press LLC, 1994.

[15] W. D. Bernard, Penerapan Termodinamika, Jakarta: Erlangga, 1988.

[16] E. Kanimba and Z. Tian, "Modeling of a thermoelectric generator device." Thermoelectrics for Power Generation-A Look at Trends in the Technology, pp.461-479, 2016.

[17] Aprianus, M. B. Rivaldo, H. S. Priskila, K. Wahyu, A. Setiawan, Panen Energi Listrik Alternatif dengan Memanfaatkan Teknologi Termoelektrik pada Aspal Jalan Raya, Universitas Kristen Satya Wacana, 2011.

[18] L. Edmunds., Heatsink Characteristics, International Rectifier, 2002.

[19] F. Keith and A. Priyono, Prinsip-Prinsip Perpindahan Panas, Jakarta: Erlangga, 1986.

[20] N. Untoro, Pengaruh Beda Temperatur Terhadap Daya Modul Termolistrik, Kendari: Universitas Haluoleo, 2012. 